\title{
Two new records of uncommon deep-sea perciform fishes from the Southwestern Atlantic
}

\author{
ALFREDO CARVALHO-FILHO ${ }^{1,4}$, GUY MARCOVALDI ${ }^{2}$, CLÁUDIO L. S. SAMPAIO ${ }^{3}$, \\ M. ISABEL G. PAIVA ${ }^{2} \&$ LUIZ A. G. DUARTE ${ }^{2}$ \\ ${ }^{1}$ Fish-Bizz Ltda. Rua Maria Garcez, 39, São Paulo, SP, 05424-070, Brasil \\ ${ }^{2}$ Projeto Tamar-ICMBio. Avenida do Farol Garcia D'Ávila, s/n, Praia do Forte, Mata de São João, BA, 48280-000, Brasil \\ ${ }^{3}$ Universidade Federal de Alagoas, Unidade de Ensino Penedo. Av. Beira Rio s/n ${ }^{\circ}$, Centro Histórico, Penedo, AL. 57.200-000 \\ ${ }^{4}$ Corresponding author. E-mail: alfie@telnet.com.br
}

\begin{abstract}
This is the third in a series of reports describing new or rare records caught with circle hooks, a method only recently being employed in exploratory fishing in Brazilian deep waters. Here we report the presence of one family and two species of perciform fishes new to, or never formerly reported from, Brazilian waters: the longfin escolar, Scombrolabrax heterolepis (Scombrolacidae), and the extremely rare ocean bass Verilus sordidus (Acropomatidae). The specimens were collected in outer shelf and slope areas at depths between 300 and 500 meters. Given the rarity of the species reported herein, we also provide an updated diagnosis for each species. We also discuss the need of adequate reports when new records are added to such a large ocean area as the Southwestern Atlantic.
\end{abstract}

Key words: Scombrolabrax, Verilus, Acropomatidae, Scombrolabracidae, deep-sea fishes, Brazil

\section{Introduction}

In the last decade, a steady increase of new records of marine fishes along the Brazilian coast has been observed. During this time, 38 new species were described and 11 revalidated, while at least another 40 species likely represent undescribed species and several works dealing with them are in preparation. In the same period dozens of described species were also added to the Brazilian fauna due to an increase of scientific expeditions and surveys, mainly the REVIZEE Program and the PROJETO TAMAR (e.g. Bernardes et al., 2005; Caires et al., 2008; Campos et al.., 2009; Carvalho-Filho et al., 2009, 2010-A, 2010-B; Melo, 2009; Melo et al.., 2009; Mincarone et al., 2008; Rotundo \& Vaske, 2009; Santos et al.., 2009).

The Scombrolabracidae is the only family that belongs to the perciform suborder Scombrolabracoidei, and has one single, marine, almost worldwide species, Scombrolabrax heterolepis Roule, 1921 (Nelson, 2006). The peculiar and unique swim bladder of the adults supports the placement of this monotypic species and family in a unique suborder (Bond \& Uyeno, 1981). To date no adult specimens were ever formerly reported from Brazilian waters or the Western South Atlantic. Several larval and adult specimens collected off the Brazilian coast are deposited in institutions around the world and discussed below. The records formerly reported in this paper confirm the presence of the species in Brazil.

The ocean bass, Verilus sordidus, belongs to the usually deep-sea, pelagic, tropical to subtropical marine family Acropomatidae (Perciformes, Percoidei), which contains seven genera and 32 species (Heemstra, 2010) or eight genera and about 33 species depending on the classification used (Nelson, 2006). Several genera placed in Acropomatidae by Nelson (1994) are now recognized in other families (Polyprionidae and Symphysanodontidae; Nelson, 2006, and Howellidae; Froese \& Pauly, 2010). The family had only three species reported from Brazil, all of the genus Synagrops: S. bellus (Goode \& Bean, 1896), S. spinosus Schultz, 
1940, and S. trispinosus Mochizuki \& Sano, 1984 (Moura \& Menezes, 2003, Lopes et al., 2003). The record herein of Verilus sordidus from Bahia presents not only a new genus and species for the Brazilian marine fish fauna and the Southwestern Atlantic, but also extends the range of the species by about 3,800 km southwards in a straight line and about 4,600 km along the South American coastline.

\section{Material and methods}

Measurements of fishes were taken with a digital caliper to the nearest hundredth of a millimeter ( $\mathrm{mm}$ ); measurements between $150 \mathrm{~mm}$ and $300 \mathrm{~mm}$ were taken with a manual caliper to the nearest tenth of mm. For fish weight we used a hand-scale to tenths of kilograms; for stomach contents and gonads, an analytical digital precision scale with an error of $0.001 \mathrm{~g}$ was used. Digital pictures were taken of the examined specimens. For further details about fishing sets, circle hooks and the research program that has been carried out by the TAMAR aiming to evaluate the circle hook's efficiency in pelagic longline fisheries, see Carvalho-Filho et al. (2009). Institutional abbreviations follow Sabaj Pérez, 2010.

Scombrolabrax heterolepis: Specimens deposited in the following institutions under collection numbers:

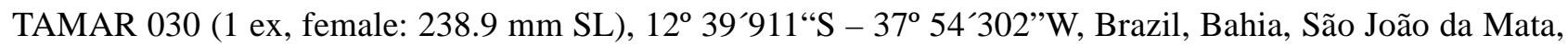
Praia do Forte, collector G. Marcovaldi, depth about 350 m, 11 December 2008; MNRJ 33607 (1 ex:117.6 mm SL), oceanographic research vessel Thalassa, Station E-0499 (13²0`872”S-38³5'922”W), off Bahia, Brazil, Revizee program, collector G. Nunan, depth about 761 m, 06 June, 2000; MNRJ 33608 (1 ex: 95.1 mm SL),

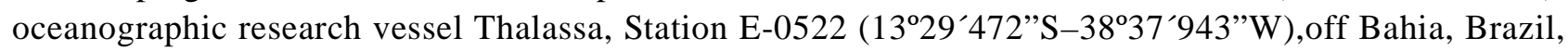
Revizee program, collector G. Nunan, depth about 1143 m, 21 June, 2000; MNRJ 33609 (6: 102.4-131.6 mm

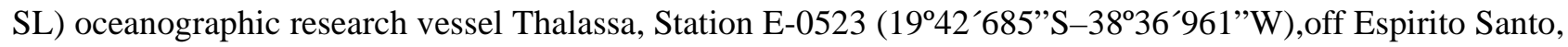
Brazil, Revizee program, collector G. Nunan, depth about 922 m, 27 June, 2000; MNRJ 33610 (1 ex: 163.6

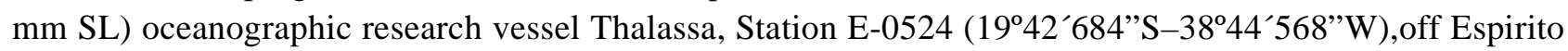
Santo, Brazil, Revizee program, collector G. Nunan, depth about 924 m, 27 June, 2000; MNRJ 33611 (1 ex: $210.0 \mathrm{~mm} \mathrm{SL}$ ) oceanographic research vessel Thalassa, Station E-0528 (19 47 $\left.581^{\prime \prime} \mathrm{S}-38^{\circ} 59^{\prime} 827^{\prime \prime} \mathrm{W}\right)$, off Espirito Santo, Brazil, Revizee program, collector G. Nunan, depth about 1237 m, 29 June, 2000; MNRJ 33612 (1 ex: $151.3 \mathrm{~mm}$ SL) oceanographic research vessel Thalassa, Station E-0535 (1956’087'S39³5'408”'W),off Espirito Santo, Brazil, Revizee program, collector G. Nunan, depth about 1001 m, 01 July, 2000.

Verilus sordidus: Specimens deposited in the following institutions under collection numbers: TAMAR 006 (1 ex, male: 232.2 mm SL), 12 39`911“S - 37 54`302”W, Brazil, Bahia, São João da Mata, Praia do Forte, collector G. Marcovaldi, depth about 430 m, 18 May 2006. UFBA 02818 (1 ex, male: 233.3 mm SL), Brazil, same data as above.

\section{Results and discussion}

\section{Scombrolabracidae}

\section{Scombrolabrax heterolepis Roule, 1921.}

(Plate 1)

Longfin escolar, Black mackerel (English); Grilo-Preto (Portuguese, Brazil); Escolarín (Spanish, Spain).

On December 11, 2008, a small "gempylid" was caught by the TAMAR. The fish was caught 10 miles off

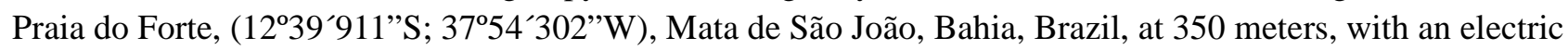
reel, circle carbon steel hooks n. 12/0, 0.60 multifilament line, $01 \mathrm{~kg}$ sinker, and sardines (Sardinella spp.) as bait. It was a mature female which measured $239 \mathrm{~mm} \mathrm{SL}$. A photograph was taken and the fish preserved. Eleven other specimens were collected off Bahia and Espírito Santo in 2000, in an oceanographic survey aboard the French oceanographic research vessel Thalassa, to provide data to the Brazilian Program 
REVIZEE; the specimens are deposited at the MNRJ and were also examined by us. The meristic and morphometric data of all specimens examined, and that of selected literature, are displayed in Table 1.A-B.

TABLE 1-A. Scombrolabrax heterolepis. Meristic data of adults.

\begin{tabular}{llllll}
\hline Counts & Roule (1921) & Grey (1960) & Fujii (1983) & Cervigón (1996) & Present Study \\
\hline Number of specimens & 1 & 1 & 5 & 1 & 12 \\
Dorsal fin spines and rays & XII + I, 14 & XII + I, 14 or 15 & XII + I, 14-15 & XII + I, 14 & XII + I, 14-15 \\
Anal fin spines and rays & 14 or 15* & II,18 & III, 16-18 & III, 15 & III,15-17 \\
Pectoral fin rays & 17 & 18 & $18-19$ & 20 & 18 \\
Lateral line scales & $48-50$ & $44-46$ & $46-50$ & 46 & $47-50$ \\
Lower gill rakers & - & 4 & $5-6$ & 6 & $4-6$ \\
\hline
\end{tabular}

*: No spines mentioned.

TABLE 1-B. Scombrolabrax heterolepis. Selected proportional measurements in rounded percentage of SL.

\begin{tabular}{lllll}
\hline & $\begin{array}{l}\text { McEachran \& Fechhelm* } \\
(2005)\end{array}$ & $\begin{array}{l}\text { Grey } \\
(1960)\end{array}$ & $\begin{array}{l}\text { Cervigón } \\
(1996)\end{array}$ & $\begin{array}{l}\text { Present Study } \\
\text { Number of specimens }\end{array}$ \\
Head Length & No mentioned & 1 & 1 & $30-34$ \\
Snout Length & $09-35$ & 34 & 34 & $09-10$ \\
Eye diameter, horizontal & $09-10$ & 09 & 08 & $08-11$ \\
Upper jaw length & $16-17$ & 10 & 11 & $13-15$ \\
Depth & $24-25$ & 16 & 15 & $22-24$ \\
Predorsal length & $40-43$ & 24 & 29 & $38-39$ \\
Preanal length & -- & 40 & -- & $67-73$ \\
Pectoral fin length & $30-36$ & 68 & -- & $31-37$ \\
Pelvic fin length & $14-15$ & 35 & 36 & $10-13$ \\
$2^{\text {nd }}$ dorsal fin base & -- & 13 & 14 & $15-18$ \\
Anal fin base & -- & 19 & -- & $19-22$ \\
\hline
\end{tabular}

* No original data; data of several authors, including juveniles and larvae.

Diagnostic characters. Based on examined specimens and literature (Roule, 1921; Grey, 1960; Bond \& Uyeno, 1980; Fujii, 1983; Nakamura, 1991; Cervigón, 1996; Nakamura \& Parin, 2002; McEachran \& Fechhelm, 2005) (Table 1.A \& B). Our data wide the range of some counts and body proportions.

Body moderately elongate and compressed; head large, the interorbital region flat; eye very large, its diameter almost as long as the conical snout; mouth large, terminal, the upper jaw protractile, the lower projecting slightly beyond the upper; teeth in upper jaw in a row of small to moderate, compressed canines, with one or two very large, stout canines on either side of symphysis; teeth of lower jaw larger than those of upper, but none large canine present; first gill arch lower limb with 4 or 6 well developed denticulate gill rakers, one of them at the angle, and the upper limb with about 10 clusters of minute spines; opercle with two flat spines on posterior border. Two dorsal fins, the first with 12 spines and almost continuous with the second that has 1 spine and 14 or 15 soft rays; base of first dorsal fin almost twice the base of the second; anal fin with 2 or 3 spines and 15-18 soft rays, opposite and similar to second dorsal fin; caudal fin forked, moderately small; pectoral fin very long with 17-19 rays and almost reaches the anal fin origin; pelvic fin below origin of pectoral fin. Scales cycloid, irregular in size and shape and very deciduous; lateral line high on body, running close to the dorsal profile, ending slightly before the end of the second dorsal fin, and with 44-50 large, not deciduous scales. Vertebrae 30, 13 precaudal and 17 caudal. The gas bladder of adult specimens has bubblellike evaginations that fit into large lateral swellings with hollows (bullae) of the $5^{\text {th }}$ to $12^{\text {th }}$ vertebral 
parapophyses, a unique character among fishes. Color dark brown to grayish brown, the fins darker and the mouth lining black. Grows to about $30 \mathrm{~cm} \mathrm{SL}$.

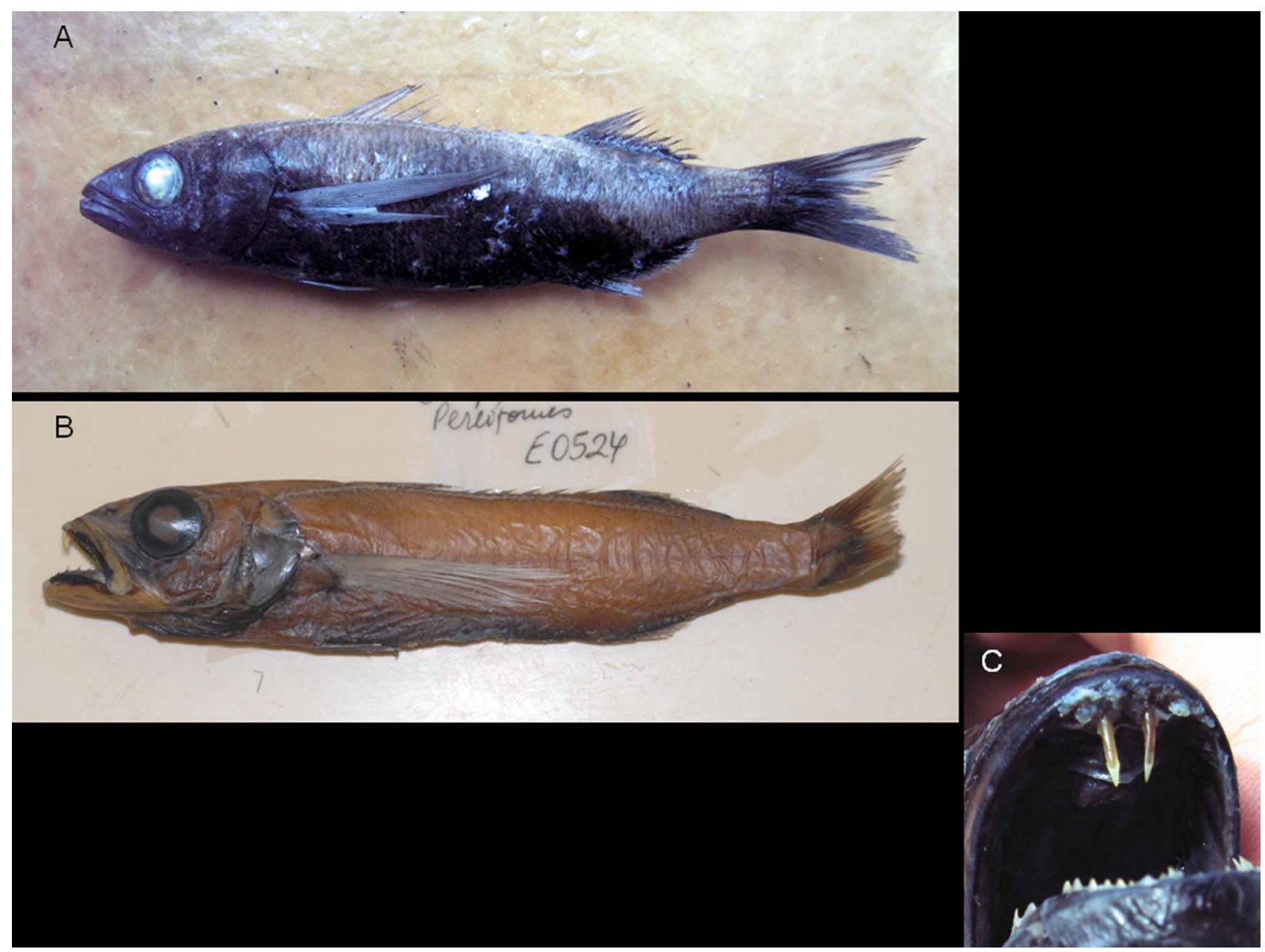

FIGURE 1. Scombrolabrax heterolepis. A. TAMAR 030, female, 238.9 mm SL. B. MNRJ 33610, 163.6 mm SL. C. Close-up of upper fangs of the TAMAR specimen.

Range. Atlantic, Pacific and Indian Oceans, in tropical and subtropical waters between 100 and 1,374 m of depth. According to several authors (e.g. McEachran \& Fechhelm, 2005; Froese \& Pauly, 2010) it wouldn't occur in the Eastern Pacific and Southeastern Atlantic, but its presence there is well documented off the west coast of South America, at about $21^{\circ} \mathrm{S}$ and $80^{\circ} \mathrm{W}$, and with a sample from Easter Island deposited at the Museo Nacional de Historia Natural de Chile (MNHNC P. 6415) (Melendez et al., 1993; Parin, 1986; Parin et al. 1997; Evseenko at al. 2004). In the Atlantic, it has been collected at sites very close to the African coast as MCZ 84369 (20 ${ }^{\circ}{ }^{\prime} \mathrm{S}$ and $6^{\circ} 59^{\prime} \mathrm{W}$ ) and RUSI 48874 (off West Coast, SE Atlantic, Cape Province, South Africa), and probably also occurs in the southeastern Atlantic as well (http://collections.mcz.harvard.edu/Fish/ FishSearch.htm and Anonymous, 2000-A).

In the Western Atlantic it occurs from Canada to, at least, southern Bahia, in Brazil, including the Gulf of Mexico, Bermuda, the Bahamas, Caribbean, Lesser Antilles, Venezuela, French Guiana and Suriname (Coad, 2008; McEachran \& Fechhelm, 2005; Costa et al., 2007; Fujii, 1983; Cervigón, 1996; Nakamura \& Parin, 2002; Smith-Vaniz et al.., 1999).

Previous records from the Southwestern Atlantic. According to the ISH collection (Anonymous, 2000B), the MCZ collection (http://collections.mcz.harvard.edu/Fish/FishSearch.htm) and Costa et al.. (2007), several specimens of the longfin escolar were collected off the Brazilian Coast since 1966. No work dealing with it had ever being published other than simple listing of the species and not formerly reporting it from the area and widening its range. Costa et al. (2007) report the capture of the specimens deposited at the MNRJ, 
from the Abrolhos Bank, off Bahia coast, between 922 and 1374 m, and list them amongst one of the most abundant species (Scombrolabrax "heterurus" in the text), a novelty for the adults elsewhere in the world. Parin et al., 1995, reported this species from the Rio Grande Rise.

Nomenclature note. Several authors consider the year of Roule's description as 1922 (e.g. Grey, 1960; Potthoff et al.., 1981; Fujii, 1983; Parin, 1986 and 1990; Melendez et al.., 1993; Santos et al.., 1997; Richards, 2006) while others consider 1921 (Boschung, 1992; Smith-Vaniz et al.., 1999; McEachran \& Fechhelm, 2005; Froese \& Pauly, 2010). The very first description of the species comes in 1921 followed in the next year by another article, in a different journal (see References). So the correct date for the first description is 1921, not 1922.

Proposed Brazilian name. "Grilo-preto", meaning "black cricket" in Portuguese. This name is adopted by the local fishermen due to its color and morphological resemblance with the Gempylidae "Grilo-branco" (white cricket), Neopinnula americana (Grey, 1953), another uncommon, silvery-white fish, collected at their main research area, Praia do Forte, Bahia.

Biology data. Habitat and depth. The specimen was caught at $350 \mathrm{~m}$ depth, and about $100-150 \mathrm{~m}$ from the ocean floor. It is a mesopelagic and benthopelagic species that inhabits the open ocean and the outer shelf and slope areas as well as underwater rises (Parin, 1990; Cervigón, 1996; Boschung, 1992; Parin et al., 1997; Evseenko at al., 2004). The capture of the species at 1,374 m reported by Costa et al. (2007) represents a new depth record.

Diet. Examining the stomach contents of Praia do Forte's specimen we found that it preyed recently on fishes, cephalopods, and crustaceans, but the remains were not identifiable. The same diet items were already reported by Parin (1990). The stomach contents weighted $0.61 \mathrm{~g}$ and in it we also found four Nematoda parasites.

Reproduction and spawning season. The specimen from Praia do Forte was a ripe female. Egg diameter was between 0.23 and $0.31 \mathrm{~mm}$ and we estimated about 220/250,000 in both ovaries that were full and had about the same size $\left(9,000 \mathrm{~mm}^{3}\right)$ and weight (4.86 g). According to Potthoff et al. (1980), the "spawning probably occurs throughout the species range and the year", because the larvae examined by them from the Atlantic Ocean were collected from February to April and from July to December.

\section{Acropomatidae}

Verilus sordidus Poey, 1860.

(Plates 2 \& 3)

Black Verilus (English), João-Mole (proposed Portuguese name, Brazil), Escolar Chino, Berregüello (Cuba); Pargo Negro (Venezuela).

In May 18, 2006, two small and unusual fishes were collected by the TAMAR, 10 miles off Praia do Forte, Mata de São João, Bahia, Brazil, in $430 \mathrm{~m}$ deep (12³9`91"S and $37^{\circ} 54^{\prime} 30^{\prime \prime} \mathrm{W}$ ), with electric reel, circle carbon steel hooks n. 12/0, a 0.60 multifilament line, $1 \mathrm{~kg}$ sinker and sardines as bait. They measured 245 and $224 \mathrm{~mm}$ SL and were identified by the first author as the extremely rare acropomatidae Verilus sordidus.

This fish is very rare and only a few specimens are deposited in collections around the world besides the Brazilian pair. The meristic and morphometric data for these specimens and that of selected literature are in Tables 2.A-B.

The specimens from Bahia are the $12^{\text {th }}$ and $13^{\text {th }}$ ever deposited in scientific institutions, (not considering USNM 271959 (1, skull, dry osteological preparation, SL unknown, off Cuba, coll. by F. Poey, apparently the same specimen of USNM 271973), and present the first record of the species for the Southwestern Atlantic Ocean and Brazil. The species range is extended by about 3,800 km southwards in a straight line and 4,600 $\mathrm{km}$ along the South American coastline. 
TABLE 2-A. Verilus sordidus. Meristic data of selected papers.

\begin{tabular}{lllllll}
\hline Counts & $\begin{array}{l}\text { Poey. } \\
(1861)\end{array}$ & $\begin{array}{l}\text { Yamanoue } \\
\text { et al. }(2009)\end{array}$ & $\begin{array}{l}\text { Cervigón } \\
(1993)\end{array}$ & $\begin{array}{l}\text { Jordan \& } \\
\text { Evermann (1898) }\end{array}$ & $\begin{array}{l}\text { Ruiz-Carus } \\
(2006)\end{array}$ & Present Study \\
\hline Number of specimens & 01 & 05 & 01 & 01 & 02 & 02 \\
Dorsal fin elements & IX-I,10 & IX-I,10 & IX-I,9 & IX-I,10 & (IX-X)-I,10 & IX-I,9-10 \\
Anal fin elements & III,7 & III,7 & III,7 & III,7 & III,7 & III,7 \\
Pectoral fin rays & 15 & 15 & 15 & No data & $14-15$ & 15 \\
Lateral line, scales & 45 & $43-45$ & 42 & 43 & 42 & $43-44$ \\
Lower gill rakers & No data & $14-16$ & 16 & 17 & $15-17$ & 16 \\
\hline
\end{tabular}

TABLE 2-B. Verilus sordidus. Selected proportional measurements in thousands of SL. Number of specimens as in Table 2-A.

\begin{tabular}{llllll}
\hline & $\begin{array}{l}\text { Yamanoue } \text { et al. } \\
(2009)\end{array}$ & $\begin{array}{l}\text { Cervigón } \\
(1993)\end{array}$ & $\begin{array}{l}\text { Jordan \& } \\
\text { Evermann (1898) }\end{array}$ & $\begin{array}{l}\text { Ruiz-Carus } \\
(2006)\end{array}$ & Present Study \\
\hline Head Length & $375-384$ & 365 & $384.6^{*}$ & $365-401$ & $341.8-379.6$ \\
Snout Length & $98-102$ & 92 & $96.1 *$ & 92 & $84.8-97.7$ \\
Eye, horizontal & $133-145$ & 129 & $134 *$ & 129 & $113.8-125.3$ \\
Interorbital & $82-86$ & 78 & $87.4 *$ & 78 & $66.9-71.8$ \\
Postorbital & $154-155$ & -- & $149.4 \#$ & -- & $124.8-156.6$ \\
Body depth & $326-337$ & 341 & $333.0 *$ & $341-395$ & $299.3-330.1$ \\
Upper jaw & $182-194$ & 184 & $192.3 *$ & $167-184$ & $163.9-188.2$ \\
Dorsal-fin base & $423-437$ & -- & $375.0 \#$ & -- & $331.5-385.8$ \\
Anall-fin base & $121-125$ & -- & 125.0 \# & -- & $105.6-112.4$ \\
Predorsal length & $415-427$ & 414 & $397.7 \#$ & $414-435$ & $391.9-442.5$ \\
Preanal length & $697-756$ & -- & $659.1 \#$ & 716 & $705.2-741.4$ \\
Pectoral fin length & $297-320$ & 317 & 316.3 & 317 & $308.3-313.6$ \\
Ventral fin length & $131-145$ & 221 & $192.3 \#$ & 221 & $170.1-184.2$ \\
\hline
\end{tabular}

Obs: Poey did not published proportions in his description. Proportions from text $(*)$ and from plate (\#), grossly rounded

Diagnostic characters. Based on the examined specimens and literature data (Poey, 1860; Jordan \& Evermann, 1898; Cervigón, 1996; Cervigón et al., 1993; Heemstra \& Yamanoue, 2002; Ruiz-Carus, 2006; Yamanoue et al., 2009). For counts and proportions see Table 2.A-B.

Body compressed, moderately deep; head moderate, covered, as the body, with somewhat caducous cycloid and very weakly ctenoid scales; bases of soft portions of dorsal fin, anal fin, pectoral fin, pelvic fin and caudal fin covered with scales. Spinous and soft dorsal fins nearly separate, the last two spines very small and connected with first soft ray by a rather low membrane; anal fin shorter than soft dorsal-fin, its origin under the third or fourth dorsal fin soft ray; proximal-middle radial of first anal-fin pterygiophore slender and without a hollow or trough. Mouth oblique and reaching to a point below pupil; a pair of canine teeth near symphysis of both jaws, eventually with a second large tooth behind in upper jaw; villiform and conical canine-like teeth posterior to the large teeth in upper and lower jaws, respectively; villiform teeth on vomer and palatine, and conical teeth on posterior surface of vomer. Preopercular margin smooth, the opercle with two weak spines and a membranous edge. Anus near origin of anal fin. Caudal fin forked. Color of fresh specimens dull black, darker on dorsum and lighter on belly; cheeks and belly suffused with purple; lower part of head with golden to yellowish cast; preserved specimens with body yellowish to dusky, darker on dorsum and silvery on belly. Grows to about $30 \mathrm{~cm}$ SL. 


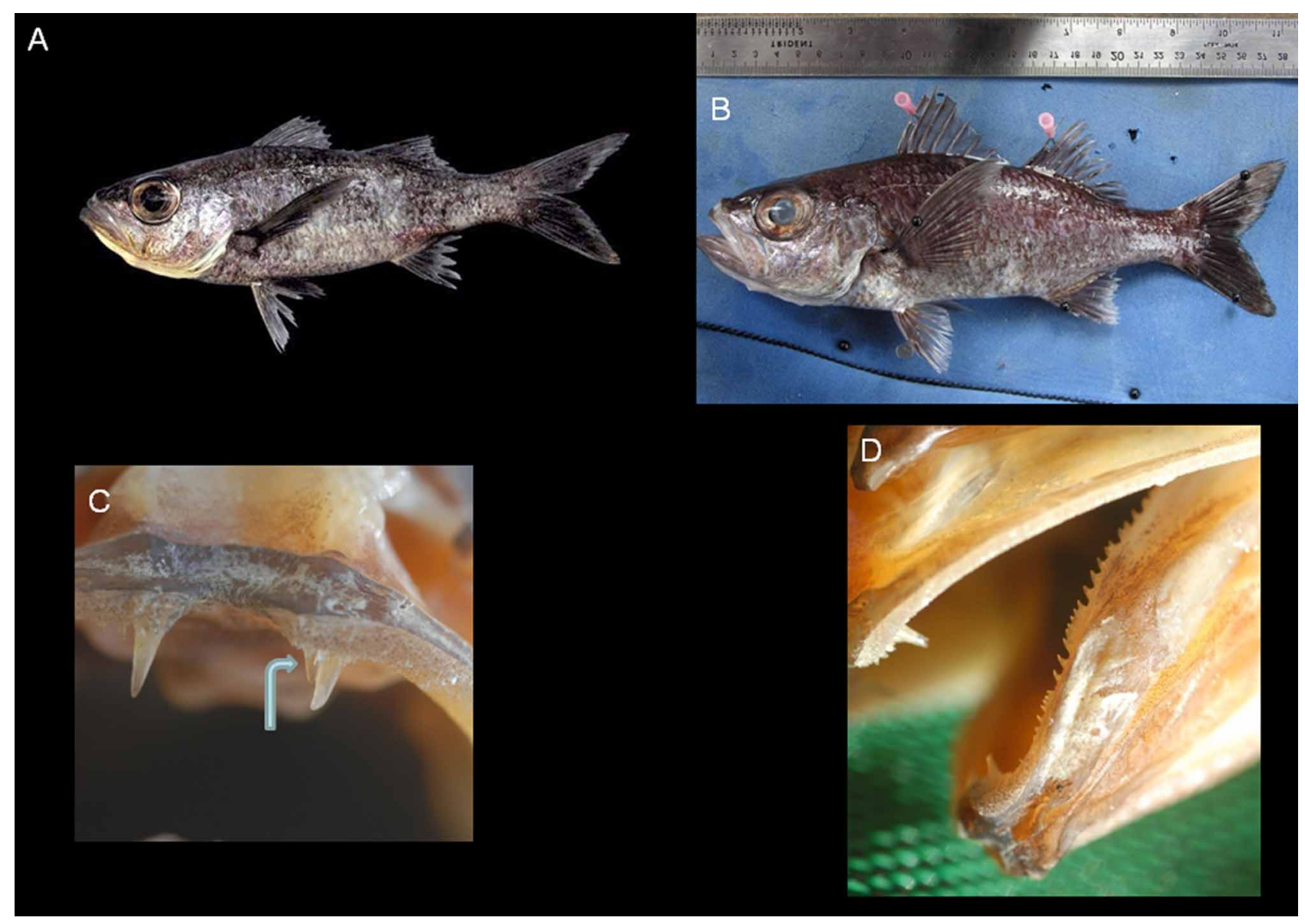

FIGURE 2. Verilus sordidus. A. TAMAR 006, male, $232.2 \mathrm{~mm}$ SL. B. UFBA 02818, male, $232.3 \mathrm{~mm}$ SL. C. Close-up of upper fangs of the TAMAR specimen; note there is a second one behind the left fang. D. Close up of lower teeth series of the TAMAR specimen.

Range. The species is reported from the Western Atlantic: Bahamas, Virgin Islands, Honduras, Puerto Rico, Cuba, Jamaica, Belize, Colombia, Venezuela and Bahia, Brazil.

Proposed Brazilian name. "João-Mole", as called by local artisanal fishermen.

Depth of occurrence. Both examined specimens were collected at 430 meters of depth. The range of depth from literature is between 100 and 600 meters (Bunkley-Williams \& Williams, 2004).

\section{Acknowledgements}

The authors are grateful to Karsten Hartel, Curatorial Associate, Ichthyology, with the Museum of Comparative Zoology, Harvard University, for his extremely valuable help, comments and whom created the "loop" with Yusuke Yamanoue, G. David Johnson and Wayne C. Starnes, who helped a lot with a wonderful mood; to Phillip Heemstra, for his support and advice; to Ramon Ruiz-Carus with the Florida Marine Research Institute, for his support, data, comments and "detective-work"; to Robert H. Robins, with the Florida Museum of Natural History, for his data and comments; to Fabiola A. Defacio for her expertise and dedicate work with the analytical digital precision scale; to Domingos Dantas de Carvalho, Renildo Dantas de Carvalho and Adriano de Jesus Santos, captain and crew of the TAMAR vessel; to Pedro Mariano Monteiro de Barros Cordeiro with the TAMAR, for his superb pictures; to Sergio de Azevedo Vinhes and Gustavo Rodamilans de Macedo, also with the TAMAR, for their help in the field; to Neca Marcovaldi and Eliane M. Pinto for their loving support; to Matthew Craig and Luiz Rocha for their help and extremely valuable 
suggestions; and finally to Gustavo Nunan, Sergio Santos, Paulo Costa, Marcelo Melo, George Olavo, Paulo D. Lopes and Ivan Sazima for their support and advice.

We also thank, in memoriam, the late Dr. Bruce Thompson, to whom this series of papers is dedicated.

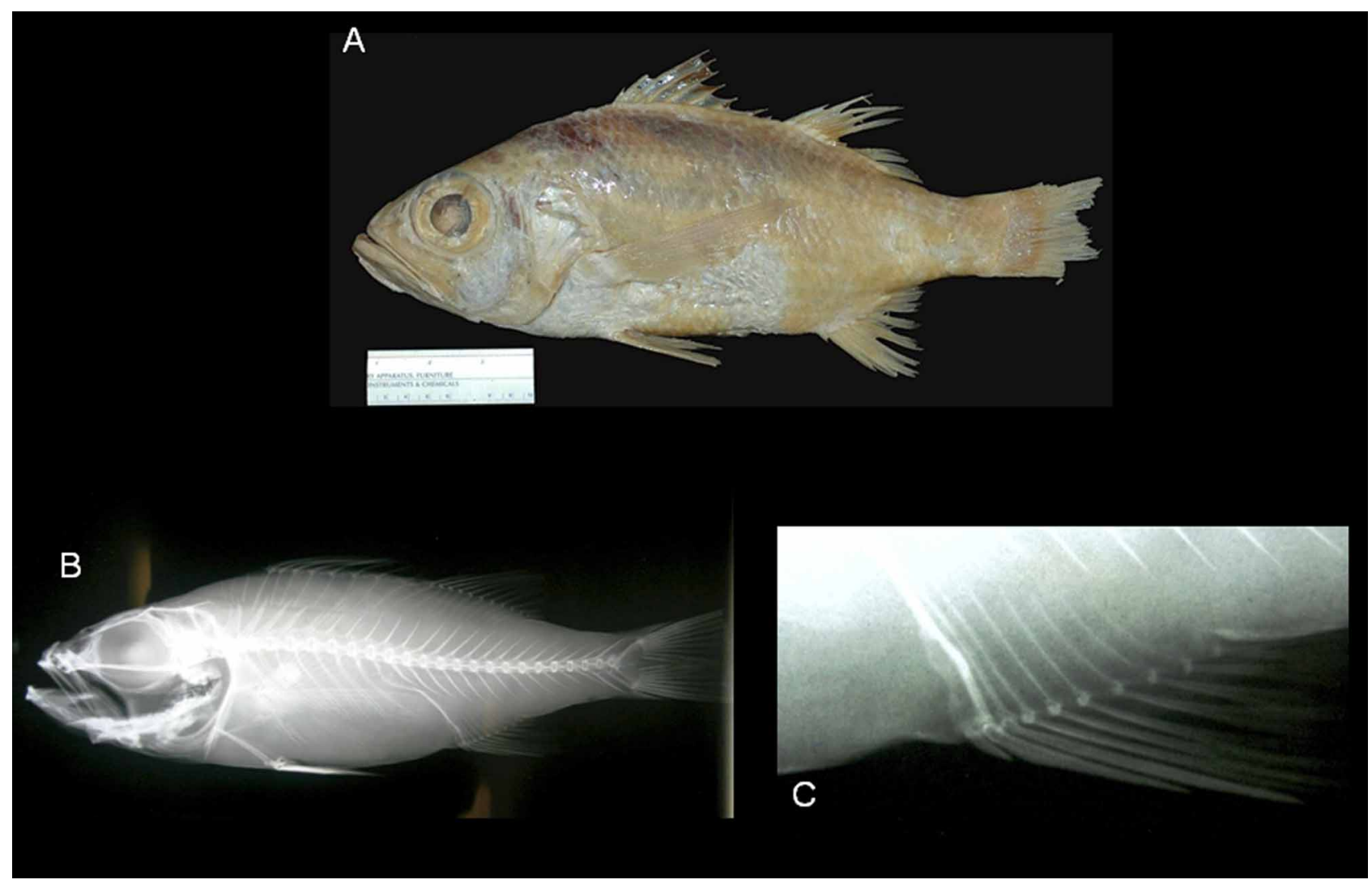

FIGURE 3. Verilus sordidus. A. MCZ 21764, neotype, $295 \mathrm{~mm}$ SL, courtesy of the Museum of Comparative Zoology, Harvard University. B. TAMAR 030, X ray. C. TAMAR 006, X ray, close-up of first anal-fin pterygiophore, slender and without a hollow or furrow.

\section{References}

Anonymous (2000-A) Fish collection database of the J.L.B. Smith Institute of Ichthyology, Grahamstown, South Africa. J.L.B. Smith Institute of Ichthyology, Grahamstown, South Africa.

Anonymous (2000-B) Fish collection database of the Institut fur Seefischerei (ISH). BIOLAB Forschungsinstitut, Hohenwestedt, Germany.

Bernardes, R.A., Figueiredo, J.L., Rodrigues, A.R., Fischer, L.G., Vooren, C.M., Haimovici, M \& RossiWomgtschowski, C.L.D.B. (2005) Peixes da Zona Econômica Exclusiva da Região Sudeste-Sul do Brasil; levantamento com armadilhas, pargueiras e rede de arrasto de fundo. Editora da Universidade de São Paulo. 295 p.

Bond, C.E. \& Uyeno, T. (1981) Remarkable Changes in the Vertebrae of Perciform Fish Scombrolabrax with Notes on Its Anatomy and Systematics. Japanese Journal of Ichthyology, 28, 3, 259-262.

Boschung, H.T. (1992) Catalogue of Freshwater and Marine Fishes of Alabama. Bulletin of the Alabama Museum of Natural History, 14. University of Alabama, $266 \mathrm{p}$.

Bunkley-Williams, L \& Williams, E.H., Jr. (2004) New Locality, Depth, and Size Records and Species Character Modifications of Some Caribbean Deep-Reef/Shallow Slope Fishes and a New Host and Locality Record for the Chimaera Cestodarian. Caribbean Journal of Science, Vol. 40, 1, 88-119.

Caires, R.A., Figueiredo, J.L. \& Bernardes, R.A. (2008) Registros novos e adicionais de teleósteos marinhos na costa brasileira. Papéis avulsos de Zoologia, S.Paulo, 48, 19, 213-225.

Campos, P., Bonecker, A.C., Castro, M.S. \& Anderson, W. (2009) First record of the fish genus Symphysanodon (Teleostei: Perciformes: Symphysanodontidae) from the western South Atlantic Ocean. Zootaxa, 2270, 63-68.

Carvalho-Filho, A., Marcovaldi, G., Sampaio, C.L.S., Paiva, M.I.G. \& Duarte, L.A.G. (2009) First report of rare pomfrets (Teleostei: Bramidae) from Brazilian waters, with a key to Western Atlantic species. Zootaxa, 2290, 1-26. 
Carvalho-Filho, A., Santos, S. \& Sampaio, I. (2010-A) Macrodon atricauda (Günther, 1880) (Perciformes: Sciaenidae), a valid species from the southwestern Atlantic, with comments on its conservation. Zootaxa, 2519, 48-58.

Carvalho-Filho, A., Santos, S. \& Sampaio, I. (2010-B) First report of Aulopus (Teleostei: Aulopidae) from Southwestern Atlantic, with a review of records and a key to Western Atlantic Aulopoidei species. Zootaxa, 2628, $27-42$.

Cervigón, F. (1996) Los peces marinos de Venezuela, Vol. IV. Fundación Científica Los Roques, Caracas, 255 p.

Cervigón, F., Cipriani, R., Fischer, W., Garibaldi, L., Hendrickx, M., Lemus, A.J., Márquez, R., Poutiers, J.M., Robiana, G. \& Rodriguez, B. (1993) Field Guide to the Commercial Marine and Brackish-Water Resources of the Northern Coast of South America. FAO Species Identification Sheets for Fishery Purposes. FAO, Rome. 513p. + XL Plates.

Coad, B.W. (2008) Annotated Cheklist of Fishes of Canada. Internet link accessed in January 2009. http:// www.briancoad.com/complete\%20list.htm

Costa, P.A.S., Braga, A.C., Melo, M.R.S., Nunan, G.W.A., Martins, A.S. \& Olavo, G. (2007) Assembléias de teleósteos demersais no talude da costa central brasileira. In. Costa, P.A.S., Olavo, G. \& Martins, A.S. (Eds.) Biodiversidade da fauna marinha profunda na costa central brasileira. Documentos REVIZEE, Score Central. Série Livros, n. 24, 87107. Museu Nacional, Rio de Janeiro.

Evseenko, S., Shcherbachev, Y., Kotlyar, A.N. \& Malikova, D. (2004) Seamount Fish Database of the P.P. Shirshov Institute of Oceanology. http://seamounts.sdsc.edu/

Froese, R. \& Pauly, D. (Eds.) Fishbase. World Wide Web Electronic Publication. www.fishbase.org, version March 2010.

Fujii, E. (1983) Scombrolabracidae In: Uyeno, T., Matsuura, K. \& Fujii, E. (Eds.) Fishes Trawled off Suriname and French Guiana, 407. JAMARC, Japan Marine Fishery Resource Research Center, Tokyo, 519 p.

Grey, M. (1960) Description of a Western Atlantic Specimen of Scombrolabrax heterolepis Roule and Notes on Fishes of the Family Gempylidae. Copeia, 3, 210-215.

Heemstra, P.C. \& Yamanoue, Y. (2002) Acropomatidae In: Carpenter, K. E. (Ed) The Living Marine Resources of the Western Central Atlantic, FAO, Rome. 2127 p., Volume 2, Bony fishes part 1 (Acipenseridae to Grammatidae), 1299-1303.

Heemstra, P.C. (2010) Acropomatidae In: Froese, R. \& Pauly, D. (Eds.), Fishbase. World Wide Web Electronic Publication. www.fishbase.org, version March 2010.

Jordan, D.S. \& Evermann, B.W. (1898) The Fishes of North and Middle America, Part II, 1283-1285. Bulletin of the United States National Museum, 47. Smithsonian Institution, Washington.

Lopes, P.R.D., Oliveira-Silva, J.T. \& Olavo, G. (2003) Synagrops trispinosus Mochizuki \& Sano, 1984 (Actinopterygii: Acropomatidae): First record from Brazil (Eastern Atlantic Ocean) with notes about its biology. Acta Biologica Leopoldinense, 25, 2, 243-249.

McEachran, J.D. \& Fechhelm, J.D. (2005) Fishes of the Gulf of Mexico, Volume 2, Scorpaeniformes to Tetraodontiformes. University of Texas Press, Austin. 1004p.

Melendez, C.R., Galvez H., O. \& Cornejo C., A. (1993) Catalogo Colecccion de Peces Depositada en el Museo Nacional de Historia Natural de Chile. Publicacion Ocasional, 47. Santiago, Chile. 224 p.

Melo, M.R.S. (2009) Revision of the Genus Chiasmodon (Acanthomoprha:Chiasmodontidae) with the description of two new species. Copeia, 3, 583-608.

Melo, M.R.S., Nunan, G., Braga, A. \& Costa, P.A.S. (2009) The deep-sea Anguilliformes and Saccopharyngiformes (Teleostei: Elopomorpha) collected on the Brazilian continental slope, between $11^{\circ}$ and $23^{\circ}$ S. Zootaxa 2234, 1-20.

Moura, R.L. \& Menezes, N.A. (2003) Acropomatidae. In: Menezes, N. A., Buckup, P. A., Figueiredo, J. L. \& Moura, R. L. (eds.), Catálogo das Espécies de Peixes Marinhos do Brasil. Museu de Zoologia da Universidade de São Paulo, $160 \mathrm{p}, 74$.

Mincarone, M.M., Nielsen, J.G. \& Costa, P.A.S. (2008) Deep-sea ophidiiform fishes collected on the Brazilian continental slope, between 110 and 23oS. Zootaxa, 1770, 41-64.

Mochizuki, K. \& Sano, M. (1984) A new perchichthyid fish Neoscombrops atlanticus from the Caribbean Sea. Japanese Journal of Ichthyology, 30, 4, 335-340.

Nakamura, I. (1991) Scombrolabracidae. In: Smith, M.M.\& Heemstra, P.C (eds.) Smith's Sea Fishes, 1st. edition, 825. Southern Book Publishers, Johannesburg, $1048 \mathrm{pp}$.

Nakamura, I. \& Parin, N.V. (2002) Scombrolabracidae In: Carpenter, K. E. (Ed) The Living Marine Resources of the Western Central Atlantic, FAO, Rome. 2127 p., Volume 3, Bony fishes part 2 (Opistognathidae to Molidae), sea turtles and marine mammals, 1806.

Nelson, J.S. (1994) Fishes of the World, third edition. John Wiley \& Sons, Inc., Hoboken, New Jersey, 600 p.

Nelson, J.S. (2006) Fishes of the World, fourth edition. John Wiley \& Sons, Inc.., Hoboken, New Jersey, 601 p.

Parin, N.V. (1986) Scombrolabracidae. In: Whitehead, P.J.P., Bauchot, M.-L., Hureau, J.-C., Nielsen, J. \& Tortonese, E. (Eds.), Fishes of the North-eastern Atlantic and the Mediterranean, UNESCO, Paris, 1473 p. Volume II, 974-975.

Parin, N.V. (1990) Scombrolabracidae. In: Quéro, J.C., Hureau, J.C., Karrer, C, Post, A \& Saldanha, L. (Eds.), Checklist of the fishes of the eastern tropical Atlantic-CLOFETA. UNESCO, Paris, 1492 p. Volume II, 973.

Parin, N.V., Mironov, A.N. \& Nesis, K.N. (1997) Biology of the Nazca and Sala-y-Gomez submarine ridges, an outpost 
of the Indo-West Pacific fauna in the Eastern Pacific ocean: composition and distribution of the fauna, its community and history. Adv. Mar. Biol. 32, 145-242.

Parin, N.V., Shcherbachev, Y.N. \& Pakhorukov, N.P. (1995) Bottom and near-bottom fishes of the Rio Grande Rise (Southwest Atlantic Ocean). Journal of Ichthyology, 35, 9, 205-219.

Poey, F. (1883) Ictiología Cubana. Transcripción, conjunction y edición científica por Dario Guitart Manday (2000). Vol. I, 141-143; Vol. III (Atlas): Láminas 88-89. Imagen Contemporanea, La Habana. 995p + 572 pl.

Potthoff, T., Richards, W.J. \& Ueyanagi, S. (1980) Development of Scombrolabrax heterolepis (Pisces, Scombrolabracidae) and comments on familial relationships. Bulletin of Marine Science, 30, 2, 329-357.

Richards, W.J. (2006) Scombrolabracidae. In: Richards, W. J. (Ed.), Early Stages of Atlantic Fishes, an Identification Guide for the Western Central North Atlantic, CRC Marine Biology Series, Taylor \& Francis Group, 2640 p. Volume II, 2151-2153.

Roule, L. (1921) Sur un nouveau poisson abyssal (Scombrolabrax heterolepis, nov. gen. nov. sp.) pêché dans les eaux de L'île Madère. Comptes Rendus Hebdomadaires dês Séances de L'Academie des Sciences, Volume 172, 24. 15341536.

Roule, L. (1922) Description de Scombrolabrax heterolepis nov. gen. nov. sp., poisson abyssal nouveau de L'île Madère. Bulletin Institute Oceanographique (Monaco), 408, 1-8.

Rotundo, M.M. \& Vaske Jr., T. (2009) Occurrence of the white anglerfish, Lophiodes beroe Caruso, 1981 (Lophiiformes: Lophiidae), in Brazilian waters. Pan-American Journal of Aquatic Sciences, 4(2), 208-211.

Ruiz-Carus, W.J. (2006) Acropomatidae. In: Richards, W. J. (Ed.), Early Stages of Atlantic Fishes, an Identification Guide for the Western Central North Atlantic, CRC Marine Biology Series, Taylor \& Francis Group, 2640 p. Volume I, 1207-1215.

Sabaj Pérez, M.H. (editor) (2010) Standard symbolic codes for institutional resource collections in herpetology and ichthyology: an Online Reference. Version 1.5 (4 Oct 2010). Electronically accessible at http://www.asih.org/, American Society of Ichthyologists and Herpetologists, Washington, DC.

Santos, R.S., Porteiro, F.M. \& Barreiros, J.P. (1997) Marine Fishes of the Azores. Annotated checklist and bibliography. Arquipélago, Life and Marine Sciences, Bulletin of the University of Azores, Supplement 1. Casa Editora, Ponta Delgada, Açores, Portugal. 244 p.

Santos, S.R., Senna, M.L.V. \& Nunan, G.W. (2009) Primeiro registro da ordem Ateleopodiformes para águas brasileiras. Boletim da Sociedade Brasileira de Ictiologia, 96, 6-7.

Smith-Vaniz, W.F., Collette, B.B. \& Luckhurst, B.E. (1999) Fishes of Bermuda: history, zoogeography, annotated checklist, and identification keys. American Society of Ichthyologists and Herpetologists Special Publication No. 4. $424 \mathrm{p}$.

Yamanoue, Y., Johnson, G.D. \& Starnes, W.C. (2009) Redescription of a poorly known acropomatid, Verilus sordidus Poey 1860, and comparison with Neoscombrops atlanticus Mochizuki and Sano 1984 (Teleostei: Perciformes). Ichthyological Research, 56, 400-406.

\section{Internet resources}

Florida Museum of Natural History: www.flmnh.ufl.edu/scripts/dbs/fish_pub.asp

Museum of Comparative Zoology: http://collections.mcz.harvard.edu/Fish/FishSearch.htm

FishBase: www.fishbase.org

National Ichthyological Collections Information Service (Brazil): www.mnrj.ufrj.br/pronex/pronex.htm 